\title{
Violências na escola: gestão de riscos e produção de saúde
}

\author{
Violence at school: risk management and health production
}

\author{
Ueberson Ribeiro Almeida \\ Universidade Federal do Espírito Santo
}

\section{RESUMO:}

Este estudo analisa as lutas que os professores de uma escola pública têm colocado em curso no trabalho para o enfrentamento das formas de violência. A pesquisa foi realizada com duas professoras e um professor de Educação Física, com os trabalhadores do corpo técnico-administrativo, pedagógico e com o vigilante da escola. O estudo teve duração de 16 meses de intenso trabalho de campo. Produziu dados por meio de conversas informais, registros de reuniões pedagógicas, momentos de planejamento, observação de aulas de $\mathrm{EF}$, entrevistas e registros no diário de campo. Opera com o conceito de atividade de Schwartz (2004), o qual a concebe como esfera das microgestões inteligentes da situação, dimensão das astúcias e da produção de "histórias" que imprimem suas marcas no trabalho. O estudo torna evidente que as "violências na escola" também podem ser produzidas "na" própria escola, sendo os docentes convocados a gerir os riscos produzidos.

Palavras-chave: violências; escola; atividade; saúde

\begin{abstract}
:
This study analyzes the struggles that the teachers of a public school have placed underway at work for the confrontation of the forms of violence. The research was carried through with two female teachers and one male teacher of Physical Education, with the technical-administrative staff, pedagogical staff, and with the school watchman. The study was conducted during 16 months of intensive fieldwork. Data were produced through informal conversations, minutes of pedagogical meetings, planning moments, PE classes observation, interviews, and registers in the field journal. It operates with Schwartz's (2004) concept of activity, which is conceived as the sphere of intelligent micromanagement of the situation, the dimension of cunning, and the production of "histories" that imprint their marks at work. The study makes evident that the "school violence" can also be produced "in" the school, as the teachers are convoked to manage the produced risks.
\end{abstract}

Key-words: violences; school; activity; health

DOI: 10.12957/mnemosine.2021.61855 


\section{Introdução}

Este artigo é parte da dissertação ${ }^{1}$ de mestrado intitulada "Nas trilhas da atividade docente: análise da relação saúde-trabalho de professores de educação física no cotidiano escolar" (ALMEIDA, 2008). A pesquisa foi realizada em uma escola Polivalente da Rede Pública de Ensino do Estado do Espírito Santo. A opção pelo espaço público atrela-se à necessidade de entender como os atores escolares e, principalmente, os professores de EF trabalham em meio à "enxurrada" discursiva midiática que apregoa a precarização das escolas públicas, a baixa qualidade do ensino e a má formação dos professores. Nessa trama, mas de modo contraditório, as políticas do Governo do Estado trazem como emblema "mais qualidade na Educação", todavia despejam "pacotes" prescritivos sobre a escola sustentados por modos de subjetivação que buscam, além de legislar e disciplinar, produzir formas de pensar e estilos de vida normalizados.

Paralelamente, no âmbito acadêmico, são produzidas pesquisas na área da Educação e da EF que focalizam o crescente adoecimento/desistência dos professores abrangendo temas como "síndrome de burnout", "professores reféns", 3 "síndrome do esgotamento profissional em professores de EF", 4 "abandono docente", 5 "desinvestimento pedagógico", 6 entre outros. Contudo, ao invés de determinar o que os professores devem fazer para não adoecer e não abandonar a profissão, fazemos um movimento inverso para compreender: como os professores estão escapando ao adoecimento e continuam trabalhando? Quais táticas ${ }^{7}$ de enfrentamento dos problemas têm sido criadas? Como os professores têm feito "usos de si" para produzirem/lutarem pela saúde na escola?

Durante a pesquisa de campo, as situações de violência na escola nos convocaram à análise: invasões do pátio externo, roubos ao patrimônio da escola, depredações e buracos no muro, "invasão" das aulas de EF por pessoas que pulavam o muro para dentro da escola. Soma-se a isso o significativo volume de reportagens que foram veiculadas na mídia, durante o período do estudo de campo, principalmente, acerca de atos de violência cometidos contra e nas escolas públicas. Diante desse problema, não previsto inicialmente no plano da pesquisa, voltamos a atenção para a compreensão das tramas que envolviam a violência anunciada pelos atores escolares, bem como às formas pelas quais eles atribuíam sentidos e buscavam enfrentar tais situações, com foco na atividade de trabalho dos professores de EF. Esta é a temática que discutiremos nesse artigo.

Para analisar as lutas que os professores têm colocado em curso no trabalho em seus processos de produção de saúde no que diz respeito ao enfrentamento das formas de 
violências, foi necessário posicionar a lupa na atividade de trabalho docente. Assim, operamos com o conceito de atividade de Schwartz (2004), o qual concebe a atividade como esfera das microgestões inteligentes da situação, dimensão das astúcias e do tratamento das variabilidades, atividade como produção de "histórias" dos sujeitos que buscam imprimir suas marcas no trabalho a fim de gerir os riscos engendrados nas brechas que se localizam entre as prescrições e o trabalho real.

Ainda embasado nesse autor, o trabalho, do ponto de vista da atividade, é compreendido como "uso", nunca simples execução, mas os que trabalham sempre colocam de "si" na atividade, sem o qual o trabalho não ocorreria. Porém, ao mesmo tempo em que os professores fazem "usos de si por si" para arbitrar e fazer escolhas no trabalho, há também um "uso" desse "si" que é feito pelos outros que compõem o ambiente escolar: os colegas de trabalho, os alunos, as pessoas da comunidade, os “outros” que estão nas prescrições e ordens advindas dos órgãos do Governo. Em síntese, o que acontece no trabalho é sempre o resultado da tensão dialética entre os "usos de si por si e pelos outros" que atravessa a atividade.

Completando a tríade conceitual atividade-trabalho-saúde, adotamos o conceito de saúde "vitalista" de Georges Canguilhem (1990). Para esse autor, saúde não está atrelada à ausência de infortúnios, mas se produz e se conquista no movimento de criação de normas que permite enfrentá-los. Nesse sentido, ser saudável é também desenvolver "margem de segurança" para lidar com as adversidades, sendo os indivíduos também sabedores daquilo que os provocam adoecimento e saúde.

Nessa perspectiva, a constante luta e movimentos empreendidos pelos sujeitos em prol da saúde no trabalho é o emblema que não pode ser escamoteado ou tornado invisível, sendo imprescindível dar visibilidade àquilo que causa sofrimento aos professores nas escolas. Saúde, portanto, não é um conceito alheio aos sujeitos; os docentes estão autorizados a dizer a respeito daquilo que os agride e os faz sofrer, o que torna a intervenção dos especialistas uma aliada na análise daquilo que, sozinhos, tanto os professores quanto os próprios especialistas teriam dificuldades para compreender, considerando somente seus modos de ver a atividade de trabalho.

A pesquisa foi realizada com duas professoras ${ }^{8}$ e um professor de Educação Física (EF) de uma escola Polivalente, com os trabalhadores do corpo técnico-administrativo, pedagógico e com o vigilante da escola. O estudo teve duração de 16 meses de intenso trabalho de campo. Produzimos dados por meio de conversas informais, registros de reuniões pedagógicas, momentos de planejamento, observação de aulas de EF, entrevistas 
e registros no diário de campo. Para o espaço desse artigo analisaremos as violências na escola por meio de três eixos que se constituíram como primordiais durante o trabalho de campo na escola: I) Formas de violência na escola e produção de processos de trabalho; II) Sutilezas e modos de produção da violência na escola e; III) O pátio externo, lugar praticado pelos professores de Educação Física: gestão de riscos e estratégias de enfrentamento das violências.

\section{Formas de violência na escola e produção de processos de trabalho}

A questão das "invasões" da escola e da violência emergiu como importante problema à organização do trabalho denunciado pelos atores escolares, principalmente, os responsáveis pela administração da escola. Presenciamos diversas tentativas feitas pela "escola" no sentido de conter e exterminar a presença de "estranhos" em seu espaço e proteger seu patrimônio imobiliário. Posicionamos a lupa no processo de produção da violência nesse contexto, analisando como os professores de EF - os quais compartilham o espaço do pátio externo com os ditos "invasores" - são afetados e lidam com tal problema.

Do ponto de vista da etimologia, violência deriva do latim vis, força e significa todo ato de força contra a natureza de algum ser; de força contra a liberdade de alguém; de violação da natureza de alguém ou de alguma coisa considerada virtuosa por uma sociedade; de transgressão contra aquelas coisas e ações que alguém ou uma sociedade define como justas e como um direito; conseqüentemente, violência é um ato de brutalidade, sevícia e abuso físico e/ou psíquico contra alguém e caracteriza relações intersubjetivas e sociais definidas pela opressão, intimidação, pelo medo e terror (CHAUÍ, 1998).

O problema da violência nas escolas públicas não é um fenômeno atual, mas remonta às décadas de 1980 e início da de 1990. A questão da segurança das escolas foi tema de pauta e da agenda política do Estado que, pontualmente, buscava suturar a depredação contra os prédios, invasões e ameaças contra alunos e professores. Segundo Spósito (2001), com a crise sociopolítica que se desenhava com o processo de abertura democrática, o clima de insegurança se agravou com a intensificação do crime organizado e do tráfico, principalmente, nas periferias dos centros urbanos do País, e assim, a escola passou a sofrer de forma mais nítida os efeitos da nova conjuntura.

Camacho (2001) não desconsidera os elementos conjunturais na compreensão da violência, mas adverte que além de estar presente em toda sociedade, a violência não fica 
restrita a determinadas classes sociais, a determinados espaços, a determinadas faixas etárias ou a determinadas épocas. Também está superada a idéia de que a violência estaria vinculada apenas e diretamente à pobreza, aos grandes centros urbanos, aos adultos e aos dias de hoje.

Tratar a questão da violência na escola estudada não implica tomar um conceito acerca desse termo e aplicá-lo aos dados e às situações, mas buscar compreender os meandros da trama que envolve a organização do trabalho e os sujeitos que vivem o cotidiano, bem como seus atos industriosos e táticas no enfrentamento dos problemas gerados nessa tensão, sem perder de vista os condicionantes sociais solicitados pela análise. E, "No caso da escola, a tarefa passa a ser rastrear, no próprio cenário escolar, as cenas constitutivas assim como as nuanças dos efeitos de violência que lá são testemunhados" (AQUINO, 1998: 11-12).

Nessa linha de raciocínio, o coordenador Sandro ${ }^{9}$ ratificou na entrevista aquilo que todos os outros entrevistados do corpo pedagógico-administrativo da escola afirmaram:

O maior problema da escola hoje é a invasão de 'elementos' estranhos. Assim, daqui você observa que eles, tanto faz de manhã, de tarde e de noite também... E a gente faz as ocorrências, quatro semanas seguidas roubaram à escola, roubaram a fiação da escola, vamos lá embaixo à polícia e fazemos a ocorrência, mas de que adianta? Ninguém vai repor. Quem tem que repor é a escola mesmo, pegar dinheiro de cantina, comprar fiação e fazer tudo de novo (Coord. SANDRO, entrevista).

Delitos, como roubos e depredação do patrimônio como buracos no muro e destruição das tabelas e aros da quadra onde se joga basquete, ocorrem, primordialmente, à noite (após o término das aulas) ou nos finais de semana, o que foge ao domínio dos trabalhadores da escola. De acordo com Spósito (2001), o quadro de precária ou ausência de segurança e o incremento da criminalidade urbana por si só não explica a complexidade da violência no espaço escolar. Mas a ausência de um dispositivo institucional democrático no interior de algumas instituições é um fator a ser considerado na intensificação de práticas de violência contra o patrimônio das escolas. Em uma pesquisa realizada em escolas de todas as regiões do Brasil, Batista e El-moor (1999) identificaram que a segurança externa (e policial) pode exercer um papel positivo na contenção das depredações ao patrimônio, embora não garanta a diminuição de roubos.

Embora não concordemos com a equação "quanto mais policiamento menor violência", é importante dizer que a violência que acomete à escola é também produzida em outras esferas e instituições sociais, não cabendo única e exclusivamente à escola e a 
seus atores resolver problemas dessa ordem que fogem aos seus domínios.

Durante o período de 13 meses no campo, não presenciamos a polícia atuando nos arredores da escola, nem por uma única vez. Percebi, pois, que os problemas de violência, os quais podem ser denominados de mais "caseiros", aqueles que envolvem pessoas da comunidade e "invasores" conhecidos pelos trabalhadores da escola, os coordenadores, pedagogas e diretor tentam dissolvê-los por meio de negociações do tipo: "Não adiantava eu bater de frente com eles, conversava numa boa, falava que na última aula eu liberaria a quadra pra eles jogarem, aí eles me obedeciam numa boa" (Coord SUZANA, entrevista).

Contudo, diante de algumas situações e pessoas que "invadem" o pátio, leia-se indivíduos ou gangues articuladas ao narcotráfico ou criminosos conhecidos apenas por seus atos de brutalidade, os atores escolares, inteligentemente, recuam e redobram a cautela para defender suas vidas. Segundo a coordenadora Suzana, há situações em que o perigo se instala antes de qualquer contato com aqueles que o representam, o que, para ela, passa a ser caso que transborda as competências e engajamentos dos atores escolares. Diz ela:

Algumas situações a gente enfrenta, mas há outras em que a gente tem que esperar o ano acabar, sentar, conversar e buscar encontrar alternativas. Do meio do ano pra cá a coisa ficou mais perigosa, porque começou a vir elementos que a gente não conhecia, elementos de outros bairros, esse pessoal que os próprios alunos falam: 'não se mete não, porque ai a barra é pesada!' (Coord. SUZANA, entrevista).

Saber esperar, não apenas ler, mas o trabalho cotidiano na escola Polivalente estudada solicita uma releitura do ambiente por parte de seus atores a cada dia, a cada pessoa que pula o muro para dentro da escola. Nesse caso, afirmamos que identificar o momento certo de agir e até mesmo de se alcançar a certeza de que, em algumas situações, o prudente é evitar o enfrentamento direto, apresenta-se como um saber profissional e inteligência do "corpo-si”" engajado na atividade. É o que diz Dejours (2005a: 18), quando postula que o trabalho não pára, não pode parar e, na complexa trama da ““[...] 'sobrevivência', homens e mulheres criam defesas contra o sofrimento padecido no trabalho. As 'estratégias de defesa' são sutis, cheias mesmo de engenhosidade, diversidade e inventividade".

Entendida como preciosa aliada na segurança escolar por autores, como Camacho (2001), Aquino (1998), Batista e El-moor (1999), Spósito (2001) e André (2003), a participação da comunidade na vida do Polivalente se resume à sombra de um conselho escolar envolvido com a prestação de contas referente à distribuição da verba. Nos outros 
aspectos,

A comunidade é omissa, porque, nessa rua, por exemplo, todo mundo vê o que acontece por aqui. Eles vêem quem rouba a escola, quem depreda tudo. A gente conserta uma grade num dia, no outro está tudo estragado. Então, esses indivíduos que pulam o muro e tal e roubam, roubaram os computadores, roubaram a cantina, a comunidade vê, a comunidade sabe e a comunidade não aciona a polícia porque tem medo também. Então eu acho, assim, nesse sentido de estar fiscalizando o patrimônio, eu acho a comunidade omissa (Coord. SUZANA, entrevista).

Não há participação da comunidade aqui, não. O diretor que não me ouça, a comunidade não é muito presente, não, eu não sei por quê (Coord. BRIDA, entrevista).

Parece que a comunidade não busca e não possui espaço efetivo na vida do Polivalente, sendo o inverso também verdadeiro, e na ausência dessa parceria, a escola fica impotente para resolver problemas que poderiam ser compartilhados, resolvidos e/ou atenuados no par escola-comunidade:

A escola também deveria estar centralizada na comunidade, é importante isso. Se houvesse mais interação, a gente poderia resolver mais problemas, mais tranqüilamente, porque teríamos o apoio da comunidade (Coord. VICTOR, entrevista).

Sem conhecer a comunidade, o professor tem receio de sair na rua para fazer um trabalho. Eles têm medo de chegar à casa de alguém para fazer uma pesquisa com os alunos, porque eles não sabem como serão recebidos, tudo isso interfere (Coord. BRIDA, entrevista).

A articulação escola-comunidade é, além de necessária, muito mais vantajosa para a escola do que para seu par, uma vez que as pessoas da comunidade, geralmente, já usufruem daquela de alguma maneira, com a escolarização dos filhos, de si próprios, com a utilização, ainda que não permitida, das quadras e do pátio como espaço de lazer e sociabilização. Queremos dizer que, negociar parcerias com a comunidade é apenas uma condição ou opção para a escola, pois a comunidade participará da vida escolar de forma consentida ou clandestina. Batista e El-moor evidenciaram, em sua pesquisa, que trancar portões e contratar guardas não se mostrou como medidas efetivas. Mas "Aquelas escolas que optaram por uma segurança externa juntamente com o apoio da comunidade (ou somente a participação desta) encontraram maior sucesso no combate à violência" (BATISTA; EL-MOOR, 1999: 157). Além de não garantir segurança aos trabalhadores da escola, os vigias contratados pela SEDU via empresas de segurança patrimonial fizeram aumentar a violência no cotidiano do Polivalente.

A escola solicitou seguranças. A SEDU mandou guardinhas pra cá, para ficarem o dia inteiro, 24 horas. Mas, quando eles faziam amizade com os bandidos lá da rua era pior do que quando não faziam (acabavam facilitando roubos), e quando não faziam, eles ficavam escondidos aqui dentro da escola em vez de ficar lá fora (Prof. PIETRO ${ }^{10}$, entrevista). 
Numa conversa com o vigia Lúcio (DIÁRIO DE CAMPO, 5-10-2006), foi possível perceber que a violência no Polivalente não apenas "pula o muro de fora para dentro" como pensam a maior parte dos entrevistados, mas também se produz de "dentro pra fora" e de "dentro para dentro" da própria escola. Estávamos no segundo patamar do pátio externo e parte dos alunos jogavam voleibol enquanto outros andavam em cima do muro. Então, o vigia Lúcio apontou para os discentes e disse:

Vigia - Esses alunos só estão vivos por causa de Deus, é Deus o culpado pela injustiça do mundo, se não fosse Deus esses alunos já estavam mortos.

\section{Pesquisador - Por quê?}

Vigia - Porque não se diz que a vida é só Deus quem pode dar e tirar! Se não fosse assim, se não fosse respeitar isso, esses meninos já tinham morrido! Eles pulam para dentro e para fora da escola no momento que bem entendem. Se eu falar com o diretor, não adianta nada, não dá nada para eles. Mas, ah! Se fosse na prisão onde eu trabalhava! Tinha que fazer igual lá, eles iriam ver só uma coisa. Tinha que fazer o seguinte: de um lado do muro ficaria a escola, do outro a gente tinha que soltar um monte de cães Rottweiller [deu um sorrisinho macabro desviando olhar], aí eu queria ver quem pularia o muro. Ainda bem que você é professor de EF, porque lidar com 'esses bichos' dentro da sala deve ser pior do que aqui fora, esses alunos são igual a bicho. Fumam maconha e não são punidos, nunca dá nada pra ninguém. (Diário de campo).

Ficamos perplexos ao ter conhecimento de que o vigia Lúcio é um ex-agente penitenciário $^{11}$ que lidava com pessoas praticantes de atividades criminosas da mais alta periculosidade e, portanto não conseguia lidar com os alunos transgressores de maneira diferenciada. Assim, ao contratar, de maneira verticalizada e terceirizada, um vigia para resolver os problemas visíveis de insegurança, a SEDU e a escola criaram outros modos de produzir violência, mais sutis, invisíveis, porém, mais graves. Assim, o que deveria produzir segurança gerou perigo velado. Torna-se necessário repensar os recursos de segurança interna na escola pública, uma vez que Batista e El-moor (1999) alertam que problemas de segurança e violência coexistem com a vigilância ostensiva interna, geralmente mal preparada para lidar com o ambiente escolar.

\section{Sutilezas e modos de produção da violência na escola}

É necessário reconhecer que a escola, leia-se, os que nela trabalham, não são vítimas unilaterais da violência cometida por pessoas que "invadem" o pátio e provocam danos à organização do trabalho ou mesmo em relação àqueles que praticam roubos e vandalismo ao patrimônio. Durante o trabalho de campo, presenciamos várias ações violentas sutis da escola em relação aos alunos: indicação de alunos por meio do critério 
de melhores notas para fazerem cursos de informática, competições e valorização dos primeiros em detrimento dos demais, atribuição de rótulos negativos a alunos com dificuldades nas disciplinas consideradas de cunho mais cognitivo e desvalorização de habilidades ligadas a práticas corporais. O que ocorre, na maior parte dos casos, é que, impotentes e estigmatizados, os alunos até desistem de estudar e se autocupabilizam pelos fracassos, mas não desistem de continuar tentando marcar seus lugares no chão da escola, para o bem e/ou para o mal. A violência não ocorre apenas na escola, mas também se produz pela escola? Violência na e da escola? Nessa trama complexa, o Coordenador Sandro nos mostra o equívoco cometido pelo pedagogo que, afetado pela indisciplina de um estudante, pretendia expulsá-lo da escola. Diz o Coordenador:

Os piores[estudantes] precisam mais da gente, mas, vai falar isso pra algumas pessoas...!!! Vai colocar isso na cabeça de uma pessoa que não quer entender assim... Nesse início de ano, quando um dos educadores viu o menino aqui que havia dado problema no ano anterior, ele falou, em tom agressivo, comigo: 'Sandro, você permitiu que esse menino voltasse a estudar?' Eu olhei pra ele assim e falei: 'Você é pedagogo mesmo, tem certeza disso?' Ele ficou quase uma semana sem falar comigo. Eu falei: 'Você é educador mesmo, você é pedagogo? Você se formou nisso mesmo? Esses meninos são os que mais precisam da gente!' (Coord. SANDRO, entrevista).

Com Spósito (2001), a fala do Coordenador Sandro produz ecos no sentido de afirmar que a crise de eficácia socializadora da escola recobre, de formas variadas, a experiência juvenil de diversas classes sociais na sua relação com o mundo adulto representado pela instituição escolar. As incivilidades sinalizariam, também, um conjunto de insatisfações manifestadas pelos alunos diante de sua experiência escolar e, ao mesmo tempo, as dificuldades da unidade escolar em criar possibilidades para que tais condutas assumam a forma de um conflito capaz de ser gerido no âmbito da convivência democrática e dialógica. Sob essa análise, é possível lançar luzes, colocando a denunciada invasão da escola entre aspas, porque "invasores", em quase sua totalidade, não são estranhos à escola, mas,

Na realidade são quase todos ex-alunos, são alunos que começaram o ano, evadiram no meio do ano e que continuam a vir pra escola não para estudar, é aquele caso: Vêm pra escola só pra 'zuar', não vêm para aprender nada. Aí, quando chega à metade do ano, eles estão cansados de levar advertência, de levar pitos, de ouvir conselhos, levar suspensão... Pelo menos quatro dos que invadem a escola, são nossos ex-alunos que abandonaram a escola (Coord. SUZANA, entrevista).

Imersos em ambientes de extrema insegurança e medo, os jovens desenvolvem estratégias na busca de segurança e formação que recusam, algumas vezes, formas grupais de sociabilidade, comuns nessa faixa etária. Ao perceber apoio, por vezes, apenas na 
família e em poucos amigos, eles tentam lidar com a ambigüidade dessa situação. Ao serem estigmatizados pela origem de sua moradia, de seus bairros e de suas condições expressas e consideradas intelectualmente defasadas, procuram tirar algumas vantagens dessa situação, dispondo-se ao enfrentamento de modo a se impor pelo medo ou pela força que essa própria representação significa diante da esperada normalidade escolar. Assim, a violência observada na escola não é exclusivamente escolar, pois exprime menos uma reação à instituição "[...] do que a demarcação de espaços de poder, uma espécie de afirmação pela violência, do direito de ser reconhecido, em situações de extrema desvantagem, decorrente do estigma" (ARAÚJO, 2000, apud SPÓSITO, 2001: 97-98). Nesse caso, faz-se necessário interpelar: quem são os "invasores" da escola? Como o desejo de "invadi-la" é produzido? Será que a invasão é apenas negativa e desorganiza o trabalho escolar ou há também nesse fenômeno faces que possibilitam aos trabalhadores da escola e aos alunos conhecer os "reais criminosos" que invadem o pátio e que podem representar perigo? A fala do coordenador Sandro pode auxiliar a compreender que os “invasores" do Polivalente, em sua maioria,

São ex-alunos daqui também. Nosso maior problema aqui é com o ex-aluno Valdir. Nós vacilamos muito quando o expulsamos da escola. Também vimos que erramos ao expulsar seu irmão, o Cláudio! São os dois que mandamos embora, porque não tinha como mais agüentar, não tinha respeito, não tinha diálogo, não tinha mais o que falar. Você chega uma hora que tem que fazer algo para dar exemplo para os outros, mas aí, depois que os mandou embora, eles pioraram, porque aí ele vinha trazendo a ganguezinha dele. Todo dia na escola quem vem aí são eles. (Coord. SANDRO, entrevista).

Embora, aparentemente, todos que pulam o muro para dentro da escola sejam denominados invasores, as formas como eles praticam o espaço institucional são diversificados, sendo o consumo e o tráfico de drogas práticas raras e, quando muito, discretas aos olhares e sem intenção de enfrentamento ou domínio sobre a autoridade dos professores de EF e dos demais trabalhadores da escola. Conta-nos a coordenadora Suzana:

Eles vêm por causa das namoradas que estão dentro da escola, pra estarem brincando porque na hora do recreio é a hora que os alunos estão brincando, poucos vêm pra passar droga, também tem isso. Eu diria que 20 por cento pulam pra isso, os outros são ex-alunos que gostam da escola e vêm pra jogar bola porque gostam da quadra. Então, tem o lado ruim e o lado bom também, tem aqueles que só querem matar a saudade: 'Ah, me deixa ficar um pouquinho, eu gosto tanto daqui.' Mas, infelizmente têm os outros que entram aqui para passar os 'aviões' de fumo. Esse é o lado ruim da história toda (Coord. SUZANA, entrevista).

Essa versão é confirmada por outros atores escolares. Segundo a Coordenadora 
Martha,

Eles voltam pra rever os colegas. Muitos foram alunos daqui, a gente já conhece (Coord. MARTHA, entrevista).

A maioria vêm para passear, rever amigos! Não sei, digamos que não seja para passar drogas, mas essa questão de rever pessoas, rever amigos (Prof ${ }^{a}$ BEATRIZ, entrevista).

Considerando as exceções, a não ser os professores de EF, os demais trabalhadores da escola se restringem ao trabalho e à vida no interior do prédio do Polivalente. A "escola" não habita, como poderia, seu próprio pátio externo. Assim, para evitar que os alunos se misturem aos ex-alunos e aos demais invasores, a administração da escola decidiu, durante a maior parte do ano letivo, manter os portões fechados no horário do recreio e, por um período menor, durante as três primeiras aulas do turno matutino.

Verificamos, com o respaldo dos atores escolares, que esse tipo de medida, além de não diminuir as tão indesejadas "invasões", criou outro problema, a insatisfação dos alunos em se sentirem trancafiados, tendo à sua disposição um pátio amplo a céu aberto. Enquanto os alunos se sentiam presos e indignados, os invasores usufruíam do pátio externo que não foi por eles conquistado, mas oferecido pela escola como o pagamento do desconhecimento de si mesma e do ausente trabalho coletivo com os elementos-chave de compreensão desse lugar: os professores de EF.

\section{O pátio externo, lugar praticado pelos professores de Educação Física: gestão de riscos e estratégias de enfrentamento das violências}

Quando eles têm que assistir aula, querem ir embora, mas quando a aula acaba, eles querem ficar na escola (Prof. PIETRO, Entrevista).

Há engajamento de um "corpo-si” no trabalho docente, que não apenas executa prescrições ou submete-se às demandas do meio, mas convoca e reconvoca saberes na prova de si da atividade. Isso implica reconhecer o trabalho como uso de si, mobilização de "si por si" em que, no processo da atividade, o sujeito convoca e reconvoca seus saberes-fazer, seus valores, afetos e julgamentos. Nesses termos, "Tudo isso é mobilizado e investido na atividade. Isso traduz um engajamento do corpo-si no trabalho que o posiciona como sujeito" (NOUROUDINE, 2004: 60).

Sob o prisma da presença de um “corpo-si” na atividade, a professora Angélica se engaja na tentativa de gerir os riscos que as pessoas que "invadem" o pátio externo demandam. Uma relação "malsucedida" com invasores ligados a atividades criminosas nesse nível poderia se constituir como face do trabalho prescrito limitador da utilização 
dos espaços para as aulas, bem como um perigo à vida.

São geralmente meninos que vêm encontrar as namoradas. Aí eles ficam esperando elas saírem. Quando há algum aluno amigo deles na turma na qual estou dando aula, a gente os chama pra conversa, pra jogar junto, para participar da conversa. Então, a relação com eles é tranqüila, até porque a maioria que vêm é adolescente, da mesma idade dos alunos, são alunos que desistiram de estudar (Prof ${ }^{a}$ ANGÉLICA $^{12}$, entrevista).

A aproximação corporal e o cuidado da professora Angélica com os ex-alunos concebidos como "invasores" da escola se traduz como "usos" engendrados que significam, além da construção de um agradável ambiente de trabalho, o estabelecimento de laços de reciprocidade e de relativa confiança que libera sua atenção para o desenvolvimento da aula, o que, na ausência de tais relações, poderia se configurar como intensificação ${ }^{13}$ do trabalho. Ao se aproximar dos seus "pares" de pátio, ela economiza esforços e ganha aliados preciosos que a informam acerca dos invasores "perigosos".

Como alerta Dejours (2005b), embora não se constitua como regra ou verdade, de modo geral, os que trabalham buscam se dedicar em fazer o melhor, fazendo usos de si e se engajando com muita energia, paixão e investimento pessoal na atividade. Portanto, é justo que esse fator humano, que essa contribuição seja reconhecida, caso contrário, quando passa pela indiferença dos parceiros e dos outros atores envolvidos direta ou indiretamente no trabalho, isso pode acarretar um sofrimento que é bastante perigoso para a saúde do trabalhador. O reconhecimento dessas artimanhas é uma reivindicação primordial dos que trabalham e, portanto, mostra-se decisivo na dinâmica da mobilização subjetiva da inteligência. Então "[...] o processo de trabalho só funciona quando os trabalhadores beneficiam a organização do trabalho com a mobilização de suas inteligências, individual e coletivamente" (DEJOURS, 2005b: 56).

Contudo, dirá Nouroudine (2004) que é necessário relativizar essa parte de autonomia dos usos de si por si, na medida em que o trabalho é também uso de si por outros. Não obstante, os protagonistas do trabalho efetuam suas atividades referindo-se a ordens e procedimentos dos quais eles não são autores exclusivos; os meios de trabalho são igualmente povoados e marcados pelas infidelidades geradas também por outros que não eles; a organização do trabalho não é concebida apenas por eles; os objetivos econômicos e financeiros que incidem sobre as condições de seu trabalho também não são concebidos por eles. Nessa tensão, o professor de EF Pietro lida da seguinte maneira com "os meninos" que "invadem" o pátio externo:

Há alguns que são muito abusados, com a maioria deles eu tenho boa relação, a gente conversa e fala: não atrapalha, não! Na sexta-feira se vocês 'pintarem' aí, eu deixo 
vocês jogarem uma bolinha. Tem que ser assim, senão não dá, não! Você tem que deixar. Esses dias o diretor chegou lá e perguntou: 'Por que esses meninos estão jogando?' Eu disse: 'É um trato que eu tenho com eles. Se eles me deixam trabalhar de segunda à quinta, na sexta eu os deixo jogarem uma pelada aí junto com a gente! Aí quando eu não quero que eles se misturem, eu deixo a quadra pra eles, eu utilizo o espaço da quadra lá de baixo' (Prof. PIETRO, entrevista).

É necessário compreender que, na trama que envolve professores de EF e invasores na disputa - talvez seja mais coerente denominar de compartilhamento do pátio externo do Polivalente - alguns acordos se dão de forma tácita: os professores necessitam do espaço para aulas e não querem sentir medo e sofrer ameaças e, por isso, evitam confrontos diretos; os invasores, que são ex-alunos, desejam conseguir continuar pulando o muro e freqüentando as quadras e as aulas de EF sem maiores problemas e, aos invasores ligados ao consumo e tráfico de drogas não lhes interessa atritos com os professores e alunos, o que poderia chamar a atenção da polícia para a escola e, pior, para seu bairro, o que é avidamente reprovável pelos outros envolvidos com atividades criminosas. Uma das facetas dessa trama pode ser evidenciada por meio da fala do professor Pietro:

Não prejudico os caras em nada, não deduro porque eles estão aí, né? Não falo nada com a direção, nem com a coordenação, não mando chamar ninguém. Eu peço, educadamente, para eles darem licença quando estão atrapalhando. Na maioria das vezes, eu obtenho sucesso nisso (Prof. PIETRO, entrevista).

Para professora Beatriz ${ }^{14}$, não são os "invasores" que criam problemas ao bom desenvolvimento do seu trabalho, mas os alunos da própria escola, que, em momentos de aula vaga, pensam ser os “donos” das quadras poliesportivas da escola:

Uma vez havia uns menininhos jogando, mas eram crianças. Eu pedi para que saíssem e eles saíram. O que eu enfrentei quando eu entrei foram os alunos que traziam bolas e jogavam nas aulas vagas. Um dos problemas é a aula vaga, pois fica muita gente lá fora que às vezes você não consegue organizar o espaço. Alguns matam aula para jogar na quadra, aí você precisa usar a quadra e nem sempre eles saem. Eu enfrentei isso no início. Havia alunos de aula vaga e eu não sei te dizer se havia alunos que não fossem da escola no meio também. Na época as duas quadras estavam funcionando, eu estava usando uma e ia precisar usar a outra, aí fui conversar com eles, falei, conversei com eles educadamente. Eles disseram que iriam sair, aí, quando eu virei as costas, eles começaram a jogar de novo, aí eu falei com eles de novo, eles disseram que iriam sair

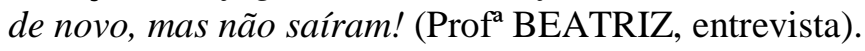

E essa docente complementa,

Os alunos que vêm de fora pra cá não me prejudicam, mas os alunos que ficam no pátio de aula vaga, estes, que acabam, de certa forma, atrapalhando um pouco a dinâmica da aula, a organização da aula, às vezes eles acabam entrando também na aula, 
participando, às vezes eles atrapalham inibindo os outros ( Prof $^{a}$ BEATRIZ, Entrevista).

No Polivalente, o trabalho escolar está organizado de forma que todos os estudantes em aulas vagas as cumpram no pátio externo, o que, a priori, facilita o trabalho da coordenação no que diz respeito ao controle do interior da escola, impedindo que tais alunos perturbem as aulas referentes às disciplinas que ocorrem nas salas de aula. Contraditoriamente, os administradores da escola não se preocupam nem se ocupam em buscar saber se o excesso de alunos em aula vaga que enviam para o pátio externo prejudica o trabalho dos professores de EF. Como já dito, "basta fechar o portão", "prender" os alunos no pátio externo que se "resolve", para a coordenação, o problema da aula vaga. Ressalto que, com o precário diálogo entre a equipe pedagógicoadministrativa e os professores de EF, as informações são esclerosadas e o poder da fala perde espaço ao silêncio e ao sentimento de resignação por parte dos docentes que, compreendendo-se como os únicos responsáveis pelo adequado desenvolvimento da aula, acabam por buscar saídas solitárias e isoladas no estabelecimento de acordos com os alunos em aula vaga, o que se mostra apenas como paliativo que permite aos docentes "respirar" no trabalho, contudo, longe de transformar a situação que se apresenta adversa.

A partir das falas da professora Beatriz e da nossa vivência com o campo da pesquisa, é possível reconhecer que a "invasão" do pátio, por parte das pessoas/ex-alunos não ligadas ao narcotráfico, ao solicitar respostas dos professores de EF como risco a ser gerido, torna-se positiva e benéfica ao trabalho desses docentes, na medida em que produz receio na administração escolar em permitir que os alunos em aula vaga ocupem o pátio externo. Reforça essa afirmação o fato de os ex-alunos serem conhecidos dos professores de EF e desempenharem o papel de informantes para tais docentes acerca das pessoas que invadem o pátio e que podem oferecer perigo. Então, reafirmamos, junto com os docentes, que há uma face positiva em relação à “invasão” do pátio para os professores de EF nesse contexto.

Os professores não são meros executadores de prescrições ou ordens predeterminadas. Na luta que se trava, muitas vezes de maneira silenciosa, o trabalho docente mostra-se vivo e arredio à clausura do sofrimento. Por mais que uma forma de gestão de ensino e/ou organização escolar coloque dificuldades ao processo de trabalho, os professores são capazes de gerir riscos por meio da atividade e produzir saúde. Não obstante, como postula Schwartz (2000), a saúde no trabalho não é uma condição gratuita, mas sempre "custa" algo aos sujeitos que se engajam na batalha por uma "bem-sucedida" 
dialética entre os "usos de si por si e pelos outros" que ocorre em toda atividade de trabalho. $\mathrm{O}$ custo não se atrela, necessariamente, a algo de valor negativo para o sujeito, mas exige a mobilização de recursos; valores e saberes em circulação e circunscritos ao patrimônio de conhecimentos do qual é parte.

Também ressaltamos a presença de uma sabedoria do "corpo-si-professor" que se constrói na confluência do biológico, do sensorial, do psíquico, do cultural, do histórico, inclusive nas atividades tachadas como mais "imateriais" (SCHWARTZ, 1998). Sabedoria capaz de levar um professor a perceber, por meio de referenciais sinestésicos não codificáveis, quem são seus possíveis parceiros no pátio externo, bem como usar de prudência para decidir não enfrentar diretamente e/ou imediatamente situações de perigo iminente à saúde, à vida.

\section{Considerações Finais}

Em síntese, é possível dizer que a violência na escola Polivalente estabeleça interface com elementos em nível macrossocial como o enfraquecimento das instituições, no que toca a seus papéis socializadores e poder subjetivantes. Também encontra ressonância na ausência do Estado, no que se refere a políticas de segurança pública para as populações dos bairros de periferia.

Compreendemos que a invasão do pátio externo por parte de pessoas ligadas ao tráfico de drogas representa um perigo ${ }^{15}$ aos professores de EF e que não cabe a eles, única e exclusivamente, a missão de lidar com tais tipos de invasões na escola. Políticas de segurança públicas gestadas com a participação da população e a viabilização de condições para que a comunidade participe da vida e da gestão escolar são importantes alternativas no trato com a violência.

A invasão do pátio, exceto por parte de pessoas que oferecem perigo, favorece o trabalho dos professores de EF. Por outro lado, a "invasão" do pátio pelos alunos em aula vaga prejudica e intensifica o trabalho dos professores de EF.

Também medidas alheias à realidade da escola, como contratação de vigilantes por meio de empresas terceirizadas, mostraram-se ineficientes. Além disso, aumentaram e agravaram a violência no Polivalente. Fechar portões, reforçar grades, prender os alunos no interior da escola são paliativos que se mostraram ineficazes e escamoteadores de modos de funcionamento escolar e de organização do trabalho capazes de engendrar, sutilmente, as condições de possibilidades para que a violência seja intensificada em múltiplas faces. 
A ausência da articulação escola-comunidade se traduz no alto custo que a escola "paga" para reparar os danos ou tentar conter os vandalismos, depredações e roubos. Além disso, pode posicionar a escola como arena de disputas por territórios entre gangues rivais envolvidas com o crime organizado. A possibilidade de compartilhar problemas comuns no dueto escola-comunidade mostra-se, nas falas de alguns atores escolares do corpo pedagógico-administrativo, como potente dispositivo democrático de contenção e diminuição da violência externa que sofre a escola.

O controle do pátio externo, bem como a segurança dos alunos depende, primordialmente, do reconhecimento dos saberes da prática dos professores de EF. O trabalho colaborativo com esses docentes e entre eles apresenta-se como elemento-chave na gestão do espaços escolares e como importante alternativa para o engendramento de condições de possibilidades no enfrentamento das diversas faces e sutilizas que a violência apresenta na escola Polivalente estudada.

\section{Referências}

ALMEIDA Ueberson Ribeiro. Nas trilhas da atividade docente: análise da relação saúdetrabalho de professores de Educação Física no cotidiano escolar. 2008. Dissertação (Mestrado em Educação Física) - Programa de Pós-Graduação em Educação Física da Universidade Federal do Espírito-Santo, Vitória, 2008.

ANDRÉ, Marli Elisa D. A. Etnografia da prática escolar. 9. ed. Campinas-SP: Papirus, 2003.

AQUINO, Júlio Groppa. A violência escolar e a crise da autoridade docente. Cadernos CEDES, Campinas, ano 19, n. 47, dez. 1998.

BATISTA, Analia Soria.; EL-MOOR, Patrícia Dario. Violência e agressão. In: CODO, Wanderley. (Org.). Educação: carinho trabalho. Petrópolis: Vozes, 1999. p. 139-160.

BRACHT, Valter et al. Educação física escolar: entre práticas inovadoras e o desinvestimento pedagógico. Universidade Federal do Espírito Santo, 2006. (Projeto de pesquisa- CNPq).

CAMACHO, Luiza Mitiko Yshiguro. As sutilezas das faces da violência nas práticas escolares de adolescentes. Educação e Pesquisa, São Paulo, v. 27, n.1, p. 123140, jan./jun. 2001.

CANGUILHEM, Georges. O normal e o patológico. 3. ed. Rio de Janeiro: Forense Universitária, 1990.

CHAUÍ, Marilena. Ética e violência. Teoria e Debate, Fundação Perseu Abramo, ano 11, n. 39, 1998. 
CODO, Wandelley (Coord.). Educação: carinho e trabalho. Petrópolis: Vozes, 1999.

DE CERTEAU, Michel . A invenção do cotidiano. 11. ed. Petrópolis: Vozes, 2005.

DEJOURS, Christophe. A banalização da injustiça social. 6. ed. Rio de Janeiro: Editora FGV, 2005a.

DEJOURS, Christophe. O fator humano. 5. ed. Rio de Janeiro: Editora FGV, 2005b.

FENSTERSEIFER, Paulo Evaldo e colaboradores. Educação física e cultura escolar: entre práticas inovadoras e o abandono do trabalho docente. Universidade Regional do Noroeste do Estado do Rio Grande do Sul - Unijuí, 2006 (Projeto de pesquisa- $\mathrm{CNPq}$ ).

FOUCAULT, Michel. História da sexualidade: o cuidado de si. Rio de Janeiro: Graal, 1985.

NOUROUDINE, Abdalla. Risco e atividades humanas: acerca da possível positividade aí presente. In: FIGUEIREDO, Marcelo et al. (Org.). Labirintos do trabalho: interrogações e olhares sobre o trabalho vivo. Rio de Janeiro: DP\&A, 2004. p. 3762 .

SANTINI, Joarez.; MOLINA NETO, Vicente. Síndrome do esgotamento profissional em professores de Educação Física. Revista da Escola de Educação Física Esporte, São Paulo, v. 19, n. 3, p. 209-222, jul./set. 2005.

SCHWARTZ, Yves. Os ingredientes da competência: um exercício necessário para uma questão insolúvel. Revista Educação \& Sociedade. Campinas, n.19, dez./1998.

SCHWARTZ, Yves. Trabalho e uso de si. França: Aix-em-Provence. Entrevista concedida a Marcelle Duc e Louis Durrive, Aix-em-Provence,11 abr. 2000.

SCHWARTZ, Yves. A abordagem do trabalho reconfigura nossa relação com os saberes acadêmicos: antecipações do trabalho. In: SOUZA-E-SILVA, M. C. P.; FAITA, D. (Org.). Linguagem e trabalho: construção de objetos de análise no Brasil e na França. São Paulo: Cortez, 2002. p. 109-137.

SCHWARTZ, Yves. Circulações, dramáticas, eficácias da atividade industriosa. Trabalho, Educação e Saúde, Manguinhos, v. 2, p. 33-55, 2004.

SPÓSITO, Marília Pontes. Um breve balanço da pesquisa sobre violência escolar no Brasil. Educação e Pesquisa, São Paulo, v. 27, n.1, p. 87-103, jan./jun. 2001.

ZAGURY, Tania. O professor refém. Rio de Janeiro: Record, 2006.

Ueberson Ribeiro Almeida Universidade Federal do Espírito Santo E-mail: uebersonribeiro@ hotmail.com 
${ }^{1}$ Dissertação de mestrado defendida em 2008, no Programa de Pós-Graduação em Educação Física do Centro de Educação Física e Desportos/Ufes.

2 Ver Codo (1999).

${ }^{3}$ Ver Zagury (2006).

${ }^{4}$ Ver Santini e Molina Neto (2005).

${ }^{5}$ Ver Fenstenseifer e colaboradores (2006).

${ }^{6}$ Ver Bracht e colaboradores (2006).

${ }^{7} \mathrm{O}$ conceito de táticas elaborado por De Certeau auxilia e complementa este ferramental analítico acerca dos "usos de si" que os professores investem na atividade de trabalho, na medida em que as táticas se caracterizam como vitória dos que parecem mais "fracos" sobre os que sustentam a posição de mais "fortes" (os poderosos, a doença, a violência das coisas ou de uma ordem etc.). Para De Certeau (2005: 47), as táticas “[...] são pequenos sucessos, artes de dar golpes, astúcias de "caçadores"”. Elas são performances mobilizadas por saberes, inteligências e astúcias.

8 Todos os trabalhadores da escola foram mantidos em anonimato. Utilizamos pseudônimos em lugar de seus nomes verdadeiros.

9 Todos nomes de sujeitos escolares utilizados são fictícios. Essa medida foi tomada para preservar a identidade dos sujeitos participantes do estudo.

${ }^{10}$ Professor de Educação Física

${ }^{11}$ Isso me leva a crer que seja necessário investigar mais profundamente os processos de formação e o contrato de trabalho dos vigilantes que atuam na escola, o que se coloca como um limite a este estudo.

12 Professora de Educação Física.

${ }^{13}$ Por exemplo, ter que redobrar a atenção para que as bolas e outros recursos didáticos não sejam roubados, bem como a intensificação da vigilância no sentido de coibir confrontos e brigas entre e os invasores e os alunos.

${ }^{14}$ Professora de Educação Física.

${ }^{15}$ A esse respeito, merece nota o assassinato de um professor de EF, o que produziu ampla repercussão no Estado (ES), durante nossa presença no campo. Ele levou dez tiros em frente à escola em que lecionava, quando se preparava para voltar para sua casa. Segundo a reportagem do jornal A Tribuna (26-9-2007), ele teria entrado em embates diretos com alunos envolvidos com o narcotráfico e que iam armados para escola. 